Artikel Penelitian

\title{
Pengaruh Penambahan Beberapa Konsentrasi Gula terhadap Stabilitas Warna Ekstrak Antosianin Buah Rukem (Flacourtia rukam Zoll. \& Mor.)
}

Effect of Various Concentration Sugar Addition on the Color Stability of Rukem Fruit Anthocyanin Extract (Flacourtia rukam Zoll. \& Mor.)

Salsabila Eka Ghina Rana, Lydia Ninan Lestario, Yohanes Martono

Program Studi Kimia, Fakultas Sains dan Matematika, Universitas Kristen Satya Wacana, Salatiga

*Korespondensi dengan penulis (nlestario@gmail.com)

Artikel ini dikirim pada tanggal 27 April 2018 dan dinyatakan diterima tanggal 29 November 2018. Artikel ini juga dipublikasi secara online melalui https://ejournal2.undip.ac.id/index.php/jatp. Hak cipta dilindungi undang-undang. Dilarang diperbanyak untuk tujuan komersial.

Diproduksi oleh Indonesian Food Technologists $®(C 2018$

\begin{abstract}
Abstrak
Penelitian ini bertujuan untuk menentukan pengaruh penambahan gula dengan konsentrasi yang bervariasi terhadap stabilitas warna ekstrak antosianin buah rukem yang terpapar cahaya lampu fluoresens berdasarkan kinetika degradasi warnanya dan menentukan konsentrasi gula yang optimal untuk meningkatkan stabilitas warna ekstrak antosianin buah rukem. Variasi konsentrasi gula yang digunakan adalah 20,40 , dan $60 \%$ (b/v). Uji stabilitas warna dilakukan terhadap ekstrak antosianin buah rukem yang disinari selama 10 jam dengan intensitas cahaya 3580, 4655 lux, dan 8544 lux. Metode yang digunakan yaitu pemodelan kinetika degradasi, dimana nilai konstanta laju degradasi $(k)$ dan nilai waktu paruh $\left(t_{1 / 2}\right)$ dihitung berdasarkan orde reaksi yang sesuai. Degradasi antosianin mengikuti orde reaksi 0 . Hasil penelitian menunjukkan bahwa penambahan gula $20 \%$ mampu meningkatkan stabilitas warna ekstrak antosianin buah rukem dibandingkan dengan kontrol (tanpa penambahan gula), terlihat dari meningkatnya waktu paruh dari 54,82 jam menjadi 61,35 jam. Namun, pada penambahan gula 40 dan $60 \%$ dapat menurunkan stabilitas warnanya dengan menurunnya waktu paruh dari 42,52 jam menjadi 31,66 jam pada intensitas 3580 lux. Kecenderungan kenaikan dan penurunan waktu paruh yang sama juga terjadi pada intensitas cahaya 4655 lux dan 8544 lux. Kesimpulannya, penambahan gula mempengaruhi stabilitas warna ekstrak antosianin buah rukem yaitu dapat meningkatkan dan menurunkan stabilitasnya.
\end{abstract}

Kata kunci: antosianin, fluoresens, gula, rukem, stabilitas

\begin{abstract}
This study is aimed to determine the effect of sugar addition with varying concentrations to the color stability of anthocyanin extract of rukem fruit exposed to fluorescent lamp lights based on color degradation kinetics and determining the optimal sugar concentration to improve color stability of anthocyanin extract of rukem fruit. Variations of sugar concentration were 20,40 , and $60 \%(\mathrm{w} / \mathrm{v})$. The color stability test was performed on the anthocyanin extract of rukem fruit which was irradiated for 10 hours with the light intensity of 3580, 4655, and 8544 lux. The degradation kinetics modeling was used as method, where the value of the degradation rate constant $(k)$ and half-life value (t1/2) were calculated according to the appropriate reaction order. Degradation of anthocyanin was analyzed using zero order reaction. The results showed that sugar addition at $20 \%$ could increase the stability of rukem fruit anthocyanin extract compared to control (without sugar addition), that was reflected by increase of half-life from 54.82 to 61.35 hours. However, addition of 40 and $60 \%$ sugar decreased the color stability with the half-life decline from 42.52 to 31.66 hours. The similar half-life increase and decrease also occured at the intensity of light 4655 and 8544 lux. As conclusion, sugar addition might increase and decrease of the color stability in the extract rukem fruit.
\end{abstract}

Keywords: anthocyanin, color stability, fluorescent light, rukem fruit, sugar addition

\begin{abstract}
Pendahuluan
Warna merupakan faktor yang penting dalam menentukan ketertarikan konsumen terhadap suatu produk pangan (Lestario et al., 2011) . Pada umumnya, produsen pangan olahan menambahkan pewarna ke dalam produknya agar menarik selera konsumen (Lestario et al., 2011). Pewarna makanan diklasifikasikan atas pewarna makanan alami dan pewarna makanan sintetik (Elizarni et al., 2014). Penggunaan pewarna makanan sintetik semakin sering digunakan karena pewarna sintetik memberikan warna yang lebih stabil dibandingkan pewarna alami.
\end{abstract}

Walaupun memiliki kelebihan, pewarna sintetik berdampak negatif bagi kesehatan tubuh. Pewarna sintetik membahayakan organ ginjal, liver, dan jantung karena dapat meningkatkan enzim aminotransferase (Amin et al., 2010). Oleh karena itu, perlu dikembangkan penggunaan pewarna alami sebagai pewarna makanan sehingga dihasilkan pewarna yang aman.

Salah satu pewarna alami yang dapat dijadikan sebagai pewarna makanan yang aman adalah antosianin (He and Giusti, 2010). Antosianin adalah pigmen yang tergolong dalam senyawa flavonoid, penyebab hampir semua warna merah, ungu sampai 
biru dalam daun, bunga dan buah pada tanaman tingkat tinggi (Lestario et al., 2014). Selain sebagai pewarna, antosianin memiliki efek yang baik bagi kesehatan tubuh manusia (He and Giusti, 2010). Salah satu fungsi antosianin adalah sebagai antioksidan (Jiao et al., 2012), anti karsinogenik, anti hipertensi dan mencegah gangguan fungsi hati (Husna et al., 2013).

Rukem merupakan salah satu buah yang mengandung antosianin, ditunjukkan dengan warna buah masak yang berwarna merah kehitaman (Swadaya, 1987). Menurut Swadaya (1987), buah rukem dapat dimakan dalam keadaan segar, dapat pula dibuat rujak, manisan dan asinan. Selain itu buah rukem yang masih muda dapat digunakaan sebagai obat. Hasil penelitian Ikram et al. (2009) menunjukkan kandungan fenolik buah rukem sebesar $40 \mathrm{mg}$ GAE/ 100 gram. Sejauh ini, pemanfaatan buah rukem hanya dikonsumsi dalam bentuk segar. Penelitian mengenai antosianin dari buah rukem masih sulit ditemui.

Stabilitas warna pigmen antosianin dipengaruhi oleh $\mathrm{pH}$, suhu, cahaya, oksigen, enzim, ion logam dan gula (Li et al., 2011). Salah satu upaya untuk meningkatkan stabilitas antosianin dengan cara ditambahkan gula. Soeroso et al. (2017) menyebutkan bahwa penambahan gula dengan konsentrasi $20 \%$ dapat meningkatkan stabilitas warna ekstrak antosianin buah murbei hitam yang terpapar cahaya lampu fluoresens. Menurut Nikkah et al. (2007), pengaruh penambahan sukrosa $20 \%$ pada jus stroberi dan murbei dapat meningkatkan stabilitas antosianin pada penyimpanan ruang gelap dan suhu dingin. Penelitian Soeroso et al. (2017), menyebutkan bahwa penambahan gula dengan konsentrasi $20 \%$ dapat meningkatkan stabilitas warna ekstrak antosianin buah murbei hitam. Selain itu, pada penelitian ini digunakan pelarut asam tartarat dimana berdasarkan hasil penelitian Lestario et al. (2014) dan Nusantara et al. (2017), pelarut asam tartarat dapat mengekstrak antosianin lebih optimal dibandingkan dengan asam asetat dan asam sitrat. Oleh karena itu, tujuan penelitian ini adalah menentukan pengaruh penambahan gula pada beberapa konsentrasi terhadap stabilitas warna ekstrak antosianin buah rukem yang terpapar cahaya lampu fluoresens berdasarkan kinetika degradasi warnanya dan menentukan konsentrasi gula yang optimal untuk meningkatkan stabilitas warna ekstrak antosianin buah rukem.

\section{Materi dan Metode}

Penelitian ini dilakukan di Laboratorium Kimia, Fakultas Sains dan Matematika, Universitas Kristen Satya Wacana, Salatiga. Penelitian ini dilaksanakan pada bulan Agustus sampai Desember 2017.

\section{Materi}

Bahan baku dari penelitian ini adalah buah rukem yang dipetik langsung dari pohonnya yang tumbuh di Universitas Kristen Satya Wacana, Salatiga, Jawa Tengah. Bahan lain yang digunakan adalah sumber sukrosa dari gula komersial (Gulaku, Indonesia). Sedangkan bahan kimia yang digunakan adalah metanol, $\mathrm{HCl}$, natrium asetat, $\mathrm{KCl}$, asam tartarat (Merck, Jerman). Peralatan yang digunakan dalam penelitian adalah neraca analitik 2 desimal (Ohaus TAJ602,US) , neraca analitik 4 desimal (Ohaus Pioneer PA214, US), moisture balance (Ohaus MB25, US), freeze dryer Thermoscientific Heto Power Dry (LL 1500, US), vortex (scilogex MX-S, US), orbital shaker (IKA KS501, Jerman), pH meter (Hanna 9812, US), lampu neon Philips, luxmeter (Lutron LX 102, Taiwan), spektrofotometer (UV-VIS mini Shimadzu 1240, Japan).

\section{Pengeringan Buah Rukem dengan Pengering Beku}

Sampel buah rukem dikeringkan dengan menggunakan pengering beku. Setelah proses pengeringan beku, sampel rukem dihaluskan dengan menggunakan grinder hingga menjadi serbuk lalu disimpan dalam wadah tertutup dan dimasukkan ke dalam freezer.

\section{Pengukuran Kadar Air}

Pengukuran kadar air buah rukem dengan menggunakan moisture balance. Setiap pengukuran dilakukan triplo.

\section{Ekstraksi Antosianin}

Ekstraksi antosianin menggunakan metode Lestario et al. (2011) yang dimodifikasi. Sebanyak 2 gram buah rukem hasil pengeringan beku direndam selama semalam dalam $30 \mathrm{ml}$ metanol yang mengandung $\mathrm{HCl} 1 \%$ pada suhu dingin $\left( \pm 10^{\circ} \mathrm{C}\right)$. Keesokan harinya larutan disaring dan filtratnya ditampung dalam labu ukur $50 \mathrm{ml}$. Ampas direndam kembali dengan pelarut yang sama sebanyak 2x10 ml menggunakan orbital shaker selama masing-masing 30 menit. Filtrat disaring dan dijadikan satu dengan hasil ekstraksi pertama kemudian labu ukur digenapkan dengan pelarut yang sama sampai garis tera.

\section{Pengukuran Antosianin Total}

Pengukuran antosianin total ekstrak buah rukem mengikuti metode Lestario et al. (2014) yang dimodifikasi. Pengukuran antosianin total buah rukem berdasarkan metode perbedaan $\mathrm{pH}$, yaitu dengan melarutkan ekstrak buah rukem dalam buffer $\mathrm{pH} 1(1,49$ gram $\mathrm{KCl}$ dalam $100 \mathrm{ml}$ akuades) dan buffer $\mathrm{pH} 4,5$ (1,64 gram natrium asetat dalam $100 \mathrm{ml}$ akuades). Kemudian diatur $\mathrm{pH}$ nya dengan $\mathrm{HCl}$ pekat sampai $\mathrm{pH} 1,0 \pm 0,1$ dan $4,5 \pm 0,1$.

Sebanyak 0,8 ml ekstrak dimasukkan kedalam dua buah tabung reaksi, kemudian masing-masing tabung ditambahkan buffer $\mathrm{pH} 1$ dan buffer $\mathrm{pH} 4,5$ sebanyak 3,2 ml. Kedua tabung didiamkan selama 15 menit, lalu diukur absorbansinya dengan spektrofotometer pada panjang gelombang $510 \mathrm{~nm}$ dan $700 \mathrm{~nm}$. Ekstraksi dan pengukuran antosianin total dilakukan tiga kali ulangan dan setiap pengukuran dilakukan triplo. Konsentrasi antosianin ditetapkan menggunakan persamaan Lambert Beer, konsentrasi antosianin dihitung sebagai sianidin 3-glikosida dengan menggunakan koefisien ekstingsi molar $29.600 \mathrm{~L} \mathrm{~mol}^{-1}$ $\mathrm{cm}^{-1}$ dan berat molekul 448,8 gram $/ \mathrm{mol}$. 


\section{Optimasi Pelarut Asam Tartarat}

Optimasi pelarut asam tartarat mengacu pada penelitian Nusantara et al. (2017) yang dimodifikasi. Sebanyak 5,00 gram buah rukem hasil pengeringan beku direndam dalam masing-masing $30 \mathrm{ml}$ larutan asam tartarat dengan variasi konsentrasi $0,5,1,2,3,4$, dan $5 \%(\mathrm{~b} / \mathrm{v})$ selama semalam pada suhu dingin $\left( \pm 10^{\circ} \mathrm{C}\right)$. Kemudian masing-masing larutan disaring dan filtratnya ditampung dalam labu ukur $25 \mathrm{ml}$. Setelah itu, residu direndam kembali dengan pelarut yang sama sebanyak 2x10 ml menggunakan orbital shaker selama 30 menit. Filtrat disaring kemudian disatukan dalam labu ukur dan digenapkan dengan pelarut yang sama. Pengukuran antosianin terekstrak dilakukan dengan metode perbedaan pH (Lestario et al., 2014). Tiap ekstrak yang diperoleh dimasukkan kedalam 2 buah tabung reaksi masing-masing sebanyak $1 \mathrm{ml}$. Tabung pertama ditambahkan dengan $3 \mathrm{ml}$ buffer $\mathrm{pH} 1$ dan tabung kedua ditambahkan dengan $3 \mathrm{ml}$ buffer $\mathrm{pH}$ 4,5. Kedua tabung didiamkan selama 15 menit, lalu diukur absorbansinya menggunakan spektrofotometer pada panjang gelombang $510 \mathrm{~nm}$ dan $700 \mathrm{~nm}$. Setiap pengukuran dilakukan triplo.

\section{Pembuatan Larutan Gula}

Pembuatan larutan gula menggunakan metode Soeroso et al. (2017). Variasi konsentrasi gula yang digunakan adalah 20, 40, dan 60\% (b/v). Pembuatan larutan gula $60 \%$ dengan cara melarutkan 60 gram sukrosa ke dalam $100 \mathrm{ml}$ akuades. Campuran tersebut diaduk hingga semua sukrosa larut, sedangkan untuk larutan gula dengan konsentrasi 20 dan $40 \%$ (b/v) dibuat dari pengenceran larutan gula $60 \%(\mathrm{~b} / \mathrm{v})$.

\section{Penambahan Gula pada Ekstrak Antosianin}

Penambahan gula pada ekstrak antosianin buah rukem menggunakan metode Soeroso et al. (2017). Ekstrak antosianin dibagi menjadi tiga bagian untuk tiap perlakuan intensitas cahaya. Kemudian ke dalam masing-masing bagian ditambahkan larutan gula dengan konsentrasi yang berbeda yaitu 20,40 , dan $60 \%$ (b/v). Perbandingan volume ekstrak antosianin dan larutan gula adalah 1:1 (v/v), sehingga konsentrasi gula didalam campuran masing-masing menjadi 10, 20, dan $30 \%$. Campuran tersebut dihomogenkan lalu didiamkan selama 15 menit. Selanjutnya ekstrak tersebut digunakan untuk pengukuran kinetika degradasi antosianin.

\section{Penentuan Panjang Gelombang Maksimum}

Penentuan panjang gelombang maksimum campuran ekstrak buah rukem dan gula menggunakan metode Lestario et al. (2014) yang dimodifikasi. Ekstrak buah rukem dengan pelarut asam tartarat 3\% yang sudah diberi berbagai konsentrasi gula dilakukan scanning panjang gelombang pada daerah $200-700$ $\mathrm{nm}$. Blanko yang digunakan yaitu asam tartarat $3 \%$. Panjang gelombang absorbansi maksimum yang diperoleh digunakan untuk pengukuran stabilitas warna ekstrak antosianin.

\section{Uji Stabilitas Warna}

Pengukuran stabilitas warna ekstrak antosianin buah rukem dilakukan dengan modifikasi metode Soeroso et al. (2017). Sebanyak $4 \mathrm{ml}$ campuran ekstrak antosianin yang diberi gula dengan konsentrasi 20, 40, $60 \%$, dan kontrol ditempatkan dalam masing-masing botol vial. Kemudian sampel dikelompokkan menjadi 3 bagian dan ditempatkan dalam tiap kotak kayu yang berukuran $40 \times 30 \times 55 \mathrm{~cm}$ untuk disinari dengan intensitas cahaya lampu fluoresens yang berbeda. Intensitas cahaya yang digunakan yaitu 18 watt (3580 lux), 23 watt (4655 lux) dan 32 watt (8544 lux). Penyinaran dengan berbagai intensitas cahaya lampu fluoresens dilakukan selama 10 jam. Pengukuran absorbansi dari setiap perlakuan dilakukan setiap 2 jam dan diukur pada panjang gelombang maksimum hasil pemindaian spektra menggunakan spektrofotometer. Kontrol yang digunakan adalah ekstrak buah rukem tanpa penambahan gula, tetapi ditambahkan akuades dengan volume yang sama dengan volume gula. Percobaan dilakukan sebanyak tiga kali ulangan dan setiap pengukuran dilakukan triplo.

\section{Analisis Data}

Stabilitas warna ditentukan melalui \% retensi warna dengan rumus: $\mathrm{B} / \mathrm{A} \times 100 \%$ dimana $\mathrm{A}$ merupakan nilai absorbansi sebelum perlakuan dan $B$ nilai absorbansi setelah perlakuan. Pengukuran degradasi warna diukur pada panjang gelombang $\lambda$ maksimum (512-515 nm). Setiap percobaan diulang sebanyak 3 kali dan pengukuran dilakukan triplo. Untuk menentukan kurva kinetika degradasi antosianin, absorbansi diplotkan retensi warna terhadap waktu penyinaran (jam) mengikuti reaksi orde 0 , 1, dan 2 . Kemudian nilai konstanta laju degradasi $(k)$ dan nilai waktu paruh $\left(t_{1 / 2}\right)$ ditentukan berdasarkan persamaan orde yang diikuti.

\section{Hasil dan Pembahasan}

\section{Kandungan Antosianin Total}

Hasil penelitian menunjukkan kandungan antosianin total buah rukem dengan pelarut metanol yang mengandung $\mathrm{HCl} 1 \%$ sebesar $88,2295 \pm 0,5128$ $\mathrm{mg} / 100$ gram berat kering atau 23,2676 $\pm 0,1354 \mathrm{mg} / 100$ gram berat basah. Kandungan antosianin total buah rukem lebih rendah bila dibandingkan dengan buah berantosianin lain seperti murbei (435 mg/100 gram berat basah) (Nusantara et al., 2017), stroberi (45-70 $\mathrm{mg} / 100$ gram berat basah), cranberi (45-100 mg/100 gram berat basah), dan ceri asam (45 mg/100 gram berat basah) (Gross, 1987). Kandungan antosianin total buah rukem juga lebih rendah bila dibandingkan dengan buah tomi-tomi (Flacourtia inermis, Roxb). Buah rukem berasal dari famili yang sama dengan buah tomi-tomi yaitu Salicaceae. Penelitian Fitriyani et al. (2018) kandungan antosianin total buah tomi-tomi ditentukan dengan metode perbedaan $\mathrm{pH}$ adalah 26,56 $\pm 0,28$ $\mathrm{mg} / 100 \mathrm{~g}$ berat segar atau 103,89 $\pm 1,08 \mathrm{mg} / 100 \mathrm{~g}$ berat kering. Perbedaan ini dapat terjadi karena warna kulit buah yang berbeda dimana kulit buah rukem berwarna merah kehitaman dan kulit buah tomi-tomi yang memiliki warna merah cerah. Selain itu, lokasi penanaman, 
kondisi tanah, dan intensitas cahaya juga dapat menyebabkan perbedaan tersebut (Lestario et al., 2011).

\section{Penentuan Panjang Gelombang Maksimum}

Penentuan panjang gelombang maksimum dilakukan dengan scanning ekstrak buah rukem pada panjang gelombang $200-700 \mathrm{~nm}$ dengan pelarut metanol yang mengandung $\mathrm{HCl} 1 \%$, yang hasilnya dapat dilihat pada Figur 1. Pada Figur 1 menunjukkan terdapat dua puncak spektra absorpsi, yaitu pada panjang gelombang $315 \mathrm{~nm}$ (dengan absorbansi 3,097) yang merupakan puncak daerah UV dan pada panjang gelombang 530 $\mathrm{nm}$ (dengan absorbansi 0,867 ) yang merupakan puncak daerah sinar tampak. Hasil ini sesuai dengan Harborne (1987) dimana puncak serapan antosianin berada pada panjang gelombang maksimum 505-535 nm.

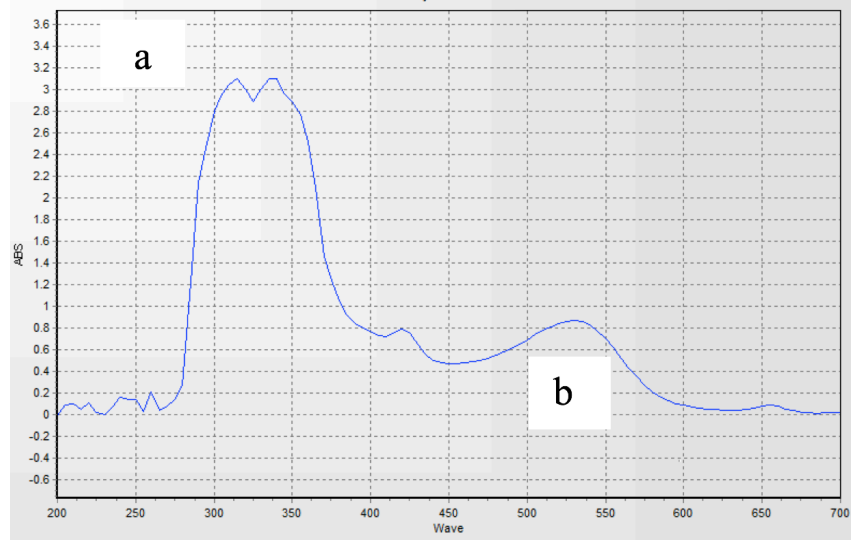

Figur 1.Hasil scanning ekstrak buah rukem pada $\lambda$ 200-700 nm dalam pelarut metanol yang mengandung $\mathrm{HCl} 1 \%$. Puncak daerah UV pada $\lambda 315 \mathrm{~nm}$ (dengan absorbansi 3,097) (b) Puncak daerah sinar tampak pada $\lambda 530 \mathrm{~nm}$ (dengan nilai absorbansi 0,867 )

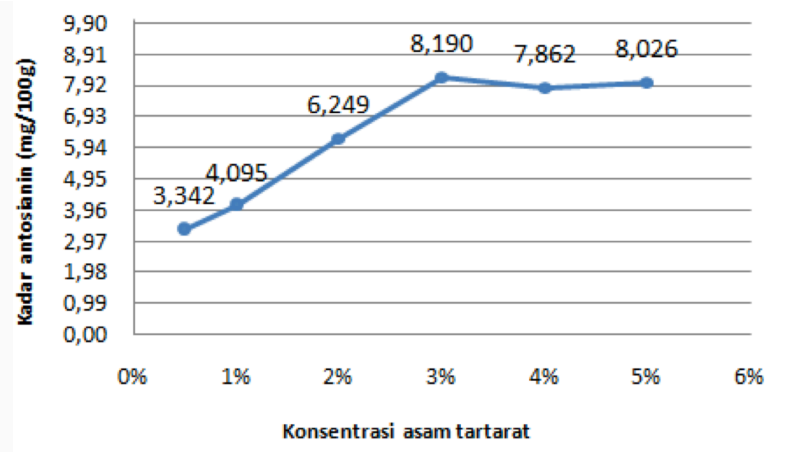

Figur 2. Rata-rata kadar antosianin rukem (berat kering) yang terekstrak dalam berbagai konsentrasi pelarut asam tartarat

Hasil scanning panjang gelombang maksimum ekstrak buah rukem dalam pelarut asam tartarat dengan berbagai konsentrasi gula dapat dilihat pada Tabel 1 yang menunjukkan sedikitnya pergeseran batokromik yaitu pergeseran absorbansi maksimum ke arah panjang gelombang yang lebih tinggi maupun pergeseran hipsokromik yaitu pergeseran absorbansi maksimum ke arah panjang gelombang yang lebih rendah. Panjang gelombang ekstrak antosianin buah rukem dengan penambahan gula 20,40 , dan $60 \%$ berturut-turut hanya bergeser $1 \mathrm{~nm}$ yaitu 513, 514, dan $515 \mathrm{~nm}$ dari yang awalnya $512 \mathrm{~nm}$ pada kontrol. Hasil ini sesuai dengan hasil penelitian Soeroso et al. (2017) yang melaporkan kecilnya tingkat pergeseran batokromik maupun hipsokromik pada warna ekstrak antosianin buah murbei hitam yang stabil.

Tabel 1. Hasil scanning panjang gelombang maksimum ekstrak antosianin buah rukem yang diberi penambahan gula dengan berbagai konsentrasi

\begin{tabular}{lc}
\hline Perlakuan & $\begin{array}{c}\text { Panjang gelombang } \\
\text { maksimum }(\mathrm{nm})\end{array}$ \\
\hline Kontrol (tanpa gula) & 512 \\
Gula 20\% & 513 \\
Gula 40\% & 514 \\
Gula 60\% & 515 \\
\hline
\end{tabular}

Tabel 2. Koefisien kolerasi $\left(R^{2}\right)$ dari data retensi degradasi ekstrak antosianin buah rukem terhadap cahaya lampu flouresens dengan penambahan berbagai konsentrasi gula yang diplotkan pada orde reaksi 0,1 dan 2

\begin{tabular}{|c|c|c|c|c|}
\hline \multirow{2}{*}{$\begin{array}{l}\text { Intensitas } \\
\text { cahaya (lux) }\end{array}$} & \multirow{2}{*}{ Perlakuan } & Orde 0 & Orde 1 & Orde 2 \\
\hline & & $\mathrm{R}^{2}$ & $\mathrm{R}^{2}$ & $\mathrm{R}^{2}$ \\
\hline \multirow{4}{*}{3580} & Tanpa gula & 0,90 & 0,89 & 0,89 \\
\hline & Gula 20\% & 0,98 & 0,98 & 0,98 \\
\hline & Gula $40 \%$ & 0,96 & 0,96 & 0,96 \\
\hline & Gula $60 \%$ & 0,97 & 0,97 & 0,97 \\
\hline \multirow{4}{*}{4655} & Tanpa gula & 0,93 & 0,92 & 0,91 \\
\hline & Gula 20\% & 0,98 & 0,98 & 0,98 \\
\hline & Gula 40\% & 0,96 & 0,96 & 0,96 \\
\hline & Gula $60 \%$ & 0,97 & 0,97 & 0,97 \\
\hline \multirow{4}{*}{8544} & Tanpa gula & 0,95 & 0,94 & 0,94 \\
\hline & Gula 20\% & 0,99 & 0,99 & 0,99 \\
\hline & Gula $40 \%$ & 0,97 & 0,97 & 0,97 \\
\hline & Gula $60 \%$ & 0,98 & 0,98 & 0,98 \\
\hline
\end{tabular}

Optimasi Pelarut Asam Tartarat

Kandungan antosianin terekstrak dalam berbagai konsentrasi pelarut asam tartarat dapat dilihat pada Figur 2 yang menunjukkan bahwa pada konsentrasi asam tartarat $0,5-3 \%$ meningkatkan kandungan antosianin, namun konsentrasi 4-5\% tidak meningkatkan kandungan antosianin. Hal ini menunjukkan bahwa konsentrasi optimum asam tartarat untuk mengekstrak antosianin buah rukem yaitu pada konsentrasi 3\%. Peningkatan jumlah antosianin terekstrak ini disebabkan oleh peningkatan jumlah ion hidrogen sehingga menurunkan $\mathrm{pH}$ larutan mendekati 1, dimana $\mathrm{pH}$ optimal untuk mengekstrak antosianin yaitu pH 1 (Fennema, 1996).

Penemuan kadar optimal ini adalah sejalan dengan hasil penelitian Lestario et al. (2014) tentang ekstraksi antosianin pada jantung pisang kepok dimana peningkatan konsentrasi asam tartarat dari konsentrasi 2 sampai $6 \%$ dapat meningkatkan kandungan antosianin, namun tidak ada peningkatan lagi pada konsentrasi 8 sampai 10\%. Konsentrasi asam tartarat yang tinggi dapat menyebabkan terjadinya hipertonik, yang memicu pada hilangnya air pada sel dan menurunnya permeabilitas membran, yang menyebabkan sel tidak dapat pecah sehingga molekul antosianin tetap di dalam vakuola dan pigmen yang pada akhirnya tidak dapat terekstrak dengan baik. Berdasarkan hasil penelitian ini, kandungan antosianin 
total yang terekstrak dengan metanol yang mengandung $\mathrm{HCl} 1 \%$ lebih besar dibandingkan kandungan antosianin total terekstrak dengan asam tartarat. Hasil ini juga sesuai dengan penelitian Lestario et al. (2014) dimana kandungan antosianin total yang terekstrak dengan metanol yang mengandung $\mathrm{HCl} 1 \%$ lebih besar dari antosianin terekstrak dengan asam tartarat. Disisi lain, hasil penelitian Nusantara et al. (2017) dan Soeroso et al. (2017) melaporkan bahwa antosianin yang terekstrak dengan pelarut metanol yang mengandung $\mathrm{HCl} 1 \%$ lebih kecil dibandingkan dengan asam tartarat. Hal ini disebabkan karena asam organik mampu mengkelat antosianin sehingga antosianin yang terekstrak dapat menjadi lebih banyak (Hosseini et al., 2016).

\section{Uji Stabilitas Warna Ekstrak Antosianin Buah}

Penentuan orde reaksi degradasi warna antosianin ekstrak buah rukem dapat dilihat pada Tabel 2. Penentuan orde reaksi berdasarkan pada nilai $R^{2}$ yang paling besar. Semakin besar nilai $R^{2}$, maka akan semakin cocok dengan model orde tersebut, sehingga apabila nilai $R^{2}$ orde 0,1 , dan 2 dibandingkan, maka kinetika degradasi dinilai mengikuti orde 0 . Hasil penelitian ini berbeda dengan hasil penelitian yang dilakukan Boranbayeva et al. (2014) dan Nusantara et al. (2017). Boranbayeva et al. (2014) menyatakan bahwa degradasi antosianin dalam jus murbei hitam mengikuti orde reaksi 1. Penelitian Nusantara et al. (2017) menemukan bahwa kopigmentasi antosianin murbei hitam dengan asam galat mengikuti orde reaksi 2 . Perbedaan ini dapat terjadi karena sampel yang digunakan berbeda, sehingga orde reaksi yang memenuhi laju degradasi antosianin juga berbeda.

Kinetika degradasi antosianin yang diberi penambahan gula dengan berbagai konsentrasi dan kontrol untuk tiap intensitas cahaya dinilai mengikuti orde reaksi 0 (Tabel 3). Nilai konstanta reaksi yang diberi gula $20 \%$ paling kecil dibandingkan dengan kontrol, gula 40 dan $60 \%$. Pada konsentrasi gula yang sama dengan penyinaran intensitas cahaya lampu flouresens yang semakin tinggi menyebabkan nilai konstanta reaksi semakin meningkat. Hal ini menunjukkan bahwa penambahan gula sebesar $20 \%$ pada intensitas cahaya 3580, 4655, dan 8544 lux mampu meningkatkan stabilitas warna ekstrak antosianin buah rukem sedangkan pada penambahan gula lebih dari $20 \%$ nilai konstanta reaksi pada semua intensitas cahaya juga meningkat.

Tabel 4. Waktu paruh (jam) pada tiap intensitas cahaya lampu fluoresens

\begin{tabular}{lccc}
\hline \multirow{2}{*}{ Perlakuan } & \multicolumn{3}{c}{ Intensitas cahaya (lux) } \\
\cline { 2 - 4 } & 3580 & 4655 & 8544 \\
\hline Kontrol (tanpa gula) & 54,82 & 50,76 & 42,92 \\
Gula 20\% & 61,35 & 58,89 & 52,69 \\
Gula 40\% & 42,52 & 38,52 & 36,95 \\
Gula 60\% & 31,66 & 30,98 & 29,96 \\
\hline
\end{tabular}

Pengaruh berbagai intensitas cahaya terhadap nilai waktu paruh ekstrak antosianin buah rukem dengan berbagai konsentrasi gula dapat dilihat pada Tabel 4 . Hasil ini menunjukkan semakin tinggi intensitas cahaya yang digunakan, semakin pendek waktu paruhnya, baik pada kontrol (tanpa penambahan gula) maupun pada ekstrak buah rukem dengan penambahan gula 20, 40, dan $60 \%$, yang berarti semakin tinggi intensitas cahaya menyebabkan ekstrak antosianin makin mudah terdegradasi. Berdasarkan Tabel 4, pada intensitas cahaya 3580 lux dan 4655 lux nilai waktu paruh ekstrak antosianin yang diberi gula sebesar $20 \%$ memiliki waktu paruh yang paling lama dibandingkan kontrol, penambahan gula 40 dan $60 \%$, yang berarti penambahan gula sebesar $20 \%$ pada intensitas cahaya 3580 dan 4655 lux dapat memperpanjang masa simpan ekstrak buah rukem, atau paling mempertahankan stabilitas antosianin. Gula mencegah terjadinya reaksi enzimatik maupun reaksi kondensasi yang menyebabkan pembentukan pigmen polimerik (Zozio et al., 2011). Hasil penelitian ini sejalan dengan penelitian Soeroso et al. (2017), bahwa sukrosa $20 \%$ dapat meningkatkan stabilitas warna ekstrak antosianin buah murbei hitam yang terpapar cahaya lampu fluoresens.

Pada penambahan gula 40 dan $60 \%$ stabilitas warna antosianin nampak menurun terlihat dari menurunnya waktu paruh. Hal ini disebabkan karena penambahan gula pada konsentrasi 40 dan $60 \%$ memicu terjadinya pembentukan senyawa hidroksi metilfurfural yang terbentuk dari hidrolisis gula pada

Tabel 3. Kinetika degradasi warna ekstrak antosianin buah rukem dengan berbagai konsentrasi gula pada intensitas cahaya yang berbeda mengikuti orde reaksi 0

\begin{tabular}{|c|c|c|c|c|}
\hline $\begin{array}{l}\text { Intensitas } \\
\text { cahaya } \\
\text { (Lux) }\end{array}$ & $\begin{array}{c}\text { Suhu } \\
\text { penyimpanan } \\
\left({ }^{\circ} \mathrm{C}\right)\end{array}$ & Perlakuan & $\begin{array}{l}\text { Persamaan garis } \\
\qquad(y=-a x+b)\end{array}$ & $\begin{array}{c}\text { Konstanta reaksi } \\
\left(\text { fraksi }^{-1} \cdot \text { jam }^{-1}\right) \\
(\overline{\mathrm{X}} \pm \mathrm{SE})\end{array}$ \\
\hline 3580 & $26-31$ & $\begin{array}{l}\text { Tanpa gula } \\
\text { Gula } 20 \% \\
\text { Gula } 40 \% \\
\text { Gula } 60 \%\end{array}$ & $\begin{array}{l}y=-0,00912 x+1,01024 \\
y=-0,00815 x+1,00082 \\
y=-0,01176 x+0,99996 \\
y=-0,01579 x+1,00503\end{array}$ & $\begin{array}{l}(0,912 \pm 0,003) \times 10^{-2} \\
(0,815 \pm 0,001) \times 10^{-2} \\
(1,176 \pm 0,005) \times 10^{-2} \\
(1,579 \pm 0,002) \times 10^{-2}\end{array}$ \\
\hline 4655 & $26-33$ & $\begin{array}{l}\text { Tanpa gula } \\
\text { Gula } 20 \% \\
\text { Gula } 40 \% \\
\text { Gula } 60 \%\end{array}$ & $\begin{array}{l}y=-0,00985 x+1,00764 \\
y=-0,00849 x+0,99907 \\
y=-0,01298 x+1,00086 \\
y=-0,01614 x+0,99876\end{array}$ & $\begin{array}{l}(0,985 \pm 0,001) \times 10^{-2} \\
(0,849 \pm 0,001) \times 10^{-2} \\
(1,298 \pm 0,002) \times 10^{-2} \\
(1,614 \pm 0,001) \times 10^{-2}\end{array}$ \\
\hline 8544 & $26-36$ & $\begin{array}{l}\text { Tanpa gula } \\
\text { Gula 20\% } \\
\text { Gula } 40 \% \\
\text { Gula } 60 \%\end{array}$ & $\begin{array}{l}y=-0,01165 x+0,99644 \\
y=-0,00949 x+0,99861 \\
y=-0,01353 x+0,99826 \\
y=-0,01669 x+0,99467\end{array}$ & $\begin{array}{l}(1,165 \pm 0,003) \times 10^{-2} \\
(0,949 \pm 0,145) \times 10^{-2} \\
(1,353 \pm 0,122) \times 10^{-2} \\
(1,669 \pm 0,006) \times 10^{-2}\end{array}$ \\
\hline
\end{tabular}


kondisi asam (Cao et al., 2009). Pada hasil penelitian ini $\mathrm{pH}$ ekstrak antosianin memiliki $\mathrm{pH}$ yang asam yaitu $\mathrm{pH}$ 2,2 dan suhu di dalam kotak kayu yang disinari lampu fluoresens dengan intensitas cahaya 4655 dan 8544 lux suhu yang dihasilkan berkisar $26-36^{\circ} \mathrm{C}$ sehingga penambahan gula pada konsentrasi 40 dan $60 \%$ mengakibatkan penurunan stabilitas warna antosianin. Pada intensitas cahaya 8544 lux, berbagai penambahan konsentrasi gula memperpendek masa simpan ekstrak buah rukem, hal ini juga terlihat dari menurunnya waktu paruh. Proses penyinaran cahaya lampu fluoresens menyebabkan degradasi warna antosianin dimana energi lampu penyinaran menyebabkan terjadinya reaksi fitokimia (Lestario et al., 2014).

\section{Kesimpulan}

Berdasarkan hasil penelitian yang diperoleh, penambahan gula dapat mempengaruhi stabilitas warna ekstrak antosianin buah rukem yaitu dapat meningkatkan dan menurunkan stabilitasnya. Selain itu, konsentrasi gula yang optimal untuk mencegah degradasi antosianin adalah $20 \%$.

\section{Ucapan Terima Kasih}

Penulis mengucapkan terima kasih atas bantuan dana penelitian Hibah Internal Universitas Kristen Satya Wacana Tahun Anggaran 2017.

\section{Daftar Pustaka}

Amin, K.A., II, H.A.H., Elsttar, A.H.A. 2010. Effect of food azo dyes tartrazine and carmoisine on biochemical parameters related to renal, hepatic function and oxidative stress biomarkers in young male rats. Food and Chemical Toxicology 48:2994-2999. DOI: 10.1016/j.fct.2010.07.039.

Boranbayeva, T., Karadeniz, F., Yilmaz, E. 2014. Effect of storage on anthocyanin degradation in black Mulberry juice and concentrates. Food and Bioprocess Technology 7(7):1894-1902. DOI: 10.1007/s11947-014-1296-8.

Cao, S., Liu, L., Lu, Q., Xu, Y., Pan, S., Wang, K. 2009. Integrated effects of asorbic acid, flavonoids and sugars on thermal degradation of anthocyanins in blood orange juice. European Food Research and Technology 228:975-983. DOI: 10.1007/s00217-009-1015-2.

Elizarni., Firdausni., Anwar, H., Sari, R. 2014. Stabilitas ekstrak kurkumin kunyit dan klorofil daun pandan menggunakan a tocoferol dan dekstrin. Jurnal Litbang Industri 4(2):97-103. DOI: 10.24960/jli.v4i2.643.97-103.

Fennema, R. 1996. Food Chemistry. 3th edition. Marcel Dekker, New York.

Fitriyani, R., Lestario, L.N., Martono, Y. 2018. Jenis dan kandungan antosianin buah tomi-tomi. Jurnal Teknologi dan Industri Pangan 29(2):137-144. DOI: 10.6066/jtip.2018.29.2.137.

Gross, J. 1987. Pigments in Fruits. Academic Press, London.

Harborne, J.B. 1987. Metode Fitokimia Penuntun Cara Modern Menganalisis Tumbuhan. ITB, Bandung.
He, J., Giusti, M.M. 2010. Anthocyanins: Natural colorants with health-promoting properties. Annual Review of Food Science and Technology 1:163-187. DOI: 10.1146/annurev.food. 080708.100754.

Hosseini, S., Gharachorloo, M., Ghiassi-Tarzi, B., Ghavami, M. 2016. Evaluation of the organic acids ability for extraction of anthocyanins and phenolic compounds from different sources and their degradation kinetics during cold storage. Polish Journal of Food and Nutrition Sciences 66(4):261269. DOI: 10.1515/pjfns-2015-0057.

Husna, N.E., Novita, M., Rohaya, S. 2013. Kandungan antosianin dan aktivitas antioksidan ubi jalar ungu segar dan produk olahannya. Agritech 33(3):296302. DOI: 10.22146/agritech.9551.

Ikram, E.H.K., Eng, H.K., Jalil, A.M.M., Ismail, A., Idris, S., Azlan, A., Nazri, H.S.M., Diton, N.A.M., Mokhtar, R.A.M. 2009. Antioxidant capacity and total phenolic content of Malaysian underutilized fruits. Journal of Food Composition and Analysis 22:388-393. DOI: 10.1016/j.jfca.2009.04.001.

Jiao, Y., Jiang, Y., Zhai, W., Yang, Z. 2012. Studies on antioxidant capacity of anthocyanin extract from purple sweet potato (Ipomoea batatas L.). African Journal of Biotechnology 11(27):7046-7054. DOI: 10.5897/AJB11.3859.

Lestario, L.N., Rahayuni, E., Timotius, K.H. 2011. Kandungan antosianin dan identifikasi antosianidin dari kulit buah Jenetri (Eleaocarpus angustifolius Blume). Agritech 31(2):93-101. DOI: 10.22146/agritech.9731.

Lestario, L.N., Yoga, M.K.W.C., Kristijanto, A.I. 2014. Stabilitas antosianin jantung pisang kepok (Musa paradisiaca $\mathrm{L}$ ) terhadap cahaya sebagai pewarna agar-agar. Agritech 34(4):374-381. DOI: 10.22146/agritech.9431.

Li, J., Walker, C.E., Faubion, J. M. 2011. Acidulant and oven type affect total anthocyanin content of blue corn cookies. Journal Science Food Agriculture 91:38-43. DOI: 10.1002/jsfa. 4173.

Nikkah, E., Khayamy, M., Heidari., Jamee, R. 2007. Effect of sugar treatment on stability of anthocyanin pigments in berries. Journal of Biological Sciences 7(8):1412-1417. DOI: 10.3923/JBS.2007.1412.1417.

Nusantara, Y.P., Lestario, L.N., Martono, Y. 2017. Pengaruh penambahan asam galat sebagai kopigmen antosianin murbei hitam (Morus nigra L.) terhadap stabilitas termal. Agritech 37(4):428436. DOI: 10.22146/agritech.22963.

Soeroso, E.G., Lestario, L.N., Martono, Y. 2017. Penambahan gula dapat meningkatkan stabilitas warna ekstrak antosianin buah murbei hitam yang terpapar cahaya lampu fluoresens. Jurnal Teknologi dan Industri Pangan 28(1):62-69. DOI: 10.6066/jtip.2017.28.1.62.

Swadaya, T.P. 1987. Mengenal Tanaman Langka Indonesia. Penebar Swadaya, Jakarta.

Zozio, S., Pallet, D., Dornier, M. 2011. Evaluation of anthocyanin stability during storage of a coloured 
drink made from extracts of the Andean blackberry (Rubus glaucus Benth.), açai (Euterpe oleracea Mart.) and black carrot (Daucus carota
L.). Fruits 66(3):203-215. DOI: 10.1051/ fruits/2011030. 